\title{
Forord - Kommunalreformen ti år efter
}

\author{
Søren Kjær Foged og Kasper Teglgaard Koch
}

Indledning

Temaet for dette nummer af Politik er kommunalreformen, der for snart ti år siden forvandlede 271 kommuner til 98. Med reformen blev den offentlige sektor i Danmark grundlæggende reorganiseret, og der blev i samme omgang gennemført en ny arbejdsdeling mellem stat, kommuner og regioner. I tillæg til traditionelle kerneområder som folkeskole, ældrepleje samt børn- og ungeområdet har kommunerne efter reformen nu ansvar for en række tidligere amtslige og statslige områder, blandt andet det specialiserede socialområde, den enstrengede beskæftigelsesindsats samt miljø og planlægning.

Det var en forventning op til reformen, at større enheder var nødvendige for at sikre det økonomiske og faglige grundlag for bæredygtighed i kommunernes opgaveløsning og udfordringer fremadrettet. Der var anerkendelse af, at især små kommuner kunne have vanskeligt ved varetagelsen af en række specialiserede servicefunktioner på faglig forsvarlig vis, og at en samling i færre, men større kommunale organisationer ville skabe en mere effektiv offentlig sektor, som kunne levere mere og bedre service for færre eller de samme ressourcer.

Fra et politologisk perspektiv er det væsentligt at evaluere reformer. Derfor er der også en naturlig interesse for at se på, hvilke effekter kommunalreformen faktisk har skabt. I 2013 gennemførtes en begrænset ministeriel evaluering af 2007-reformen med henblik på justeringer inden for reformens rammer. Sammenlignet med den ministerielle evaluering har dette temanummer til formål at belyse reformens betydning $i$ et bredere politologisk perspektiv. Temanummerets bidragsydere er førende forskere, der analyserer og vurderer de mulige effekter af kommunalreformen.

Kurt Houlberg viser i den første artikel, at kommunesammenlægningerne i 2007 har indfriet forhåndsforventningerne til forbedret økonomisk styringskapacitet, og har givet økonomiske stordriftsfordele på administrations- og vejområdet i de sammenlagte kommuner. Disse stordriftsfordele har dog ikke ført til fald i de samlede udgifter, og produktiviteten i kommunerne ser ikke ud til at være øget som følge af kommunesammenlægningerne. Hvordan det er gået med effektiviteten i den kommunale opgaveløsning, ved vi ikke.

I den anden artikel beskriver Marius Ibsen udviklingen i kommunernes interne organisation siden kommunalreformen i 2007. Diskussionen om kommunernes administration har især drejet sig 
om valget af overordnet ledelse (forvaltningsmodel eller direktionsmodel) og graden af administrativ decentralisering. Status i dag er, at mellem en tredjedel og halvdelen af kommunerne (afhængigt af definitionen) har en egentlig direktionsmodel. Kommuner, der blev sammenlagt, har en signifikant større tilbøjelighed til at have en direktion, og det forekommer sandsynligt, at reformens vægt på at øge helhedstækningen og sikre bedre vilkår for strategisk ledelse er en væsentlig baggrund for ændringerne.

Niels Jørgen Mau Pedersen præsenterer i den tredje artikel tendenser i stat-kommuneforholdet med særligt fokus på økonomiaftaler og sanktionssystemet. Artiklen undersøger udviklingen fra 1980 til 2016 og peger på, at kommunernes muligheder for at forhandle udgiftsforøgelser hjem i økonomiaftalerne er blevet begrænset siden reformen. Til gengæld er styring gennem udgiftsrammer og ekstra tilskudsfinansiering i forbindelse med økonomiaftalerne blevet mere almindeligt, hvorimod tidligere tiders styring af kommunerne gennem krav til likviditet er trådt $\mathrm{i}$ baggrunden. Samtidig vises det, hvordan udrulningen af de kollektive og individuelle sanktioner $\mathrm{i}$ årene efter kommunalreformen muligvis kan forklares med afprøvningen af disse styringsinstrumenter $\mathrm{i}$ forbindelse med kommunalreformen.

I den fjerde artikel giver Sune Welling Hansen et review af studier, der har undersøgt de lokaldemokratiske konsekvenser af kommunalreformen. Der fokuseres særligt på studier der har anvendt sammenlægningerne til at studere sammenhængen mellem størrelsen på politiske systemer og demokratiets tilstand. Det overordnede billede er, at studiernes resultater i høj grad stemmer overens med den eksisterende litteratur, der ikke har kunnet påvise nævneværdige forskelle i lokaldemokratiets tilstand på tværs af kommuner af forskellig størrelse.

\section{Et tema med pludselig relevans?}

Spørgsmålet om hvordan politiske enheders størrelse påvirker økonomisk effektivitet, faglig bæredygtighed og demokratisk medbestemmelse er et centralt tema i politisk tænkning. Kommunalreformen i 2007 indeholder derfor potentielt vigtige læringspunkter for fremtidige reformer i både ind- og udland. Sådanne læringspunkter er velkomne, da vidensgrundlaget for reformer af den offentlig sektors politiske og administrative indretning ofte er beskedent. Da Strukturkommissionens betænkning fra 2004 blev lagt til grund for reformen i 2007, var der da også "betydelig usikkerhed forbundet med vurderingen af en kommunal minimumsstørrelse" (Strukturkommissionen 2004, 36). Erfaringerne efter 2007-reformen må således forventes at indeholde en viden, som pludselig kan få 
stor betydning for fremtidige ændringer af den offentlige sektor i Danmark eller en egentlig ny dansk strukturreform.

Mindre end ti år efter den seneste reforms ikrafttræden kan det måske virke forhastet at tænke på en ny reform - der gik trods alt mere end 35 år siden den forrige i 1970! På den anden siden kan en række forhold pege på, at vi ikke kommer til at vente til 2045 før det kommunale landkort igen ændres. Herunder vil vi pege på fire faktorer, der kan trække i retning af en ny kommunalreform, og dermed pludselig gøre erfaringerne fra 2007-reformen så meget desto mere relevante.

For det første må man konstatere, at der løbende sker justeringer af det kommunale myndighedsområde. Det gælder for eksempel dannelsen af Udbetaling Danmark, der siden 2012 har overtaget ansvaret for en række tidligere kommunale områder, herunder folkepension og boligstøtte. En tilsvarende ændring af kommunernes myndighedsområde gælder reformen af Redningsberedskabet, hvor 87 beredskaber fra 2016 er reduceret til 20 beredskabsenheder, som kommunerne driver i fællesskab. Hertil kommer en række tværkommunale samarbejder, som kommunerne frivilligt indgår på tværs af kommunegrænser. Disse eksempler viser, at det ikke ligger fjernt for hverken staten eller kommunerne selv at bryde de geografiske og opgavemæssige rammer, der blev bestemt med reformen fra 2007.

Et pres for fremtidige kommunesammenlægninger kan være resultatet af et statsligt ønske om at ensrette service og vilkår på tværs af kommunerne (f.eks. Blom-Hansen 2009), men efterhånden kan løbende justeringer, som beskrevet ovenfor, også gøre en sammenhængende reform naturlig ud fra et kommunalt synspunkt. Da de to vestjyske kommuner Holstebro og Struer i december 2015 for eksempel stemte om sammenlægning, begrundede borgmesteren i Holstebro Kommune netop forslaget i, at samarbejdet mellem de to kommuner i forvejen var højt, og at en sammenlægning dermed var et naturligt næste skridt (Randers Amtsavis 2016). Dette var dog en opfattelse, som borgerne i begge kommuner afviste med betydelige flertal.

For det andet kan man også pege på interne pres i kommunerne, hvor de forudsatte stordriftsfordele ved reformen ikke i alle tilfælde har vist sig lige tydelige. Det gælder for de kommuner, som ikke lagde sig sammen og kun har oplevet en mindre effektivisering af eksempelvis de administrative udgifter i forhold til sammenlægningskommunerne (Blom-Hansen, Houlberg \& Serritzlew 2014). Men det kan også gælde for kommuner, der trods sammenlægningen i 2007 fortsat er markant mindre end gennemsnitskommunen. Selvom den gennemsnitlige kommunestørrelse målt på indbyggertal blev øget fra cirka 19.000 til ca. 55.000, så er spredningen i kommunestørrelse fortsat stor, og et indbyggertal mellem 20.000 og 30.000 (hvilket var Strukturkommissionens anbefaling) 
udgør i dag en lille kommune. Dermed rammes kommunerne også forskelligt af de stadigt flere sundhedsopgaver fra regionerne, den stigende efterspørgsel på specialviden på miljøområdet, øgede krav til dokumentation og evaluering, et eskalerende "pulje-bureaukrati" samt fortsat nye procesregler på en lang række områder. En del mindre kommuner kan således føle sig opgave- og finansieringsklemte, fordi grundlaget for stordriftsfordelene ganske enkelt ikke er til stede. I nogle tilfælde er det måske mere korrekt at tale om deciderede "smådriftsulemper", eksempelvis i forhold til det enstrengede og kommunalt forankrede beskæftigelsessystem, hvor både de økonomiske risici og nødvendigheden af bred faglig koordinering presser de mindste kommuner mest. Med andre ord: Hvis ambitionen med kommunalreformen var at sikre økonomisk og faglig bæredygtighed over hele det kommunale landkort, er det således en udfordring, at nye initiativer og krav fra statens side rammer kommunerne forskelligt på grund af deres varierende størrelser.

Endelig kan vi for det tredje ende med at se en ny kommunalreform som en konsekvens af den fortsatte diskussion om de fem regioners fremtid. Det regionale niveau var således knapt dannet før det blev sat til debat, og i de seneste år er diskussionen om en omorganisering eller nedlæggelse af regionerne med jævne mellemrum blusset op. Da KL og Danske Regioner i efteråret 2014 præsenterede en mulig - men dog senere afvist - fusion af de to interesseorganisationer, blev det i nogle kredse udlagt som regionernes forberedelse til et nyt liv under en borgerlig regering, der vil af med dem. Efter længere tids uvished afslørede Venstre da også kort før Folketingsvalget i sommeren 2015 sin holdning til regionernes fremtid, og gav med udspillet 'Prioritér sundheden' regionerne fire år til at bevise deres værd og leve op til en række krav. En eventuel nedlæggelse af det regionale niveau vil meget nemt kunne åbne et vindue for reformer af også den kommunale sektor. Dette skyldes, at de mindste kommuners udfordringer med at overkomme den nuværende opgaveportefølje mildest talt ikke kan forventes at blive mindre, hvis yderligere regionale opgaver skal overtages. Dermed kan en nedlæggelse af regionerne også ende med at luge ud i de nuværende 98 kommuner.

At se på læringspunkterne fra kommunalreformen i 2007 handler i sidste ende om at skabe det bedst mulige beslutningsgrundlag for fremtidige reformer. Det er håbet, at vi med dette temanummer kan bidrage til at konsolidere den fælles viden om effekterne af kommunalreformen i 2007. Dermed kan vi forhåbentligvis gå til næste reformproces med et væsentligt bedre udgangspunkt end det, som den engelske professor Kenneth Newton måtte konkludere tilbage i 1982:

"We can conclude with confidence that, under certain not well understood circumstances, it
may, or may not, be more, or less, economical to have larger or smaller, local authorities" (Newton 1982, 193). 
Litteratur

Blom-Hansen, J 2009, 'Det kommunale selvstyres stille død', in J Blom-Hansen \& J. Elklit (red.), Perspektiver på politik, 206-211, Academica, Århus.

Blom-Hansen, J, K Houlberg \& S Serritzlew 2014, 'Size, Democracy, and the Economic Costs of Running the Political System', American Journal of Political Science, vol. 58, no. 4, pp. 790803.

Newton, K 1982, 'Is Small Really so Beautiful? Is Big Really so Ugly? Size, Effectiveness and Democracy in Local Government', Political Studies, vol. 30 no. 2, pp. 190-206.

Randers Amtsavis 2016, 'Borgerne i Holstebro og Struer skal stemme om sammenlagning', Lokaliseret 11. april 2016. http://amtsavisen.dk/politik/borgerne-i-holstebro-og-struer-skal-stemme-omsammenlaegning.

Strukturkommissionen 2004, Strukturkommissionens Betcenkning Bind I. Hovedbetcenkningen, Indenrigs- og Sundhedsministeriet, København. 